\title{
Developing Reading Materials Through Local Based Needs at SDN 100107 Lobulayan South Tapanuli North Sumatera
}

\author{
Ade Efrina Nasution \\ English Applied Linguistics Study Program Postgraduate School \\ Universitas Negeri Medan (UNIMED) \\ Medan, Indonesia \\ e-mail: adeefrina@gmail.com
}

\author{
I WY Diregeyasa \\ English Applied Linguistics Study Program Postgraduate School \\ Universitas Negeri Medan (UNIMED) \\ Medan, Indonesia
}

\author{
Zainuddin \\ English Applied Linguistics Study Program Postgraduate School \\ Universitas Negeri Medan (UNIMED) \\ Medan, Indonesia
}

\begin{abstract}
Nowadays, the developing and appreciating material based on students local based needs is very attractive. The purposes of this study are: 1) To find out the existing English reading materials used for the students of sixth grade at SDN 100107 Lobulayan in South Tapanuli regency; 2) To find out English reading material are needed by the students of sixth grade at SDN 100107 Lobulayan in South Tapanuli regency. This study is employed by implementing Research and Development design by Borg and Gall, 1983 but in implementing the model is simplified and adapted to Dirgeyasa (2011) become four steps: 1) evaluation and need analysis, 2) developing new material, 3) validating material, 4) final revision. The target of clients of this research was 29 correspondents which consisted of 25 students of SDN 100107 Lobulayan, 1 English teacher they are taken by using total sampling technique, 2 lecturers and 1 stakeholder is taken by using random sampling technique. The data was collected by questionnaire, documentation, and interview. The result of the study showed that the existing reading material used was less relevant with the needs of students of SDN 100107 Lobulayan in terms of topics, basic competences, assessment, and learning activities. After gaining the data from the evaluation and need analysis, it was found that the relevant reading material needed by the students of SDN 100107 Lobulayan are the material which related to their local based needs contains reading text; go to Aek Sijornih, I like 'daun ubi tumbuk', Salacca (local fruits), local Vegetables.
\end{abstract}

Keywords $-R \& D$; developing reading material; local based needs

\section{INTRODUCTION}

In the context of Indonesian education, English as a foreign language has been learned by Indonesian learners since they were in Elementary School. According to the latest government policy as stated in the 2013 Curriculum, English at Elementary schools is now only a local-content subject taught once a week. Indonesia has also started English teaching earlier as compared to that previously which started at grade 7. Since the establishment of the decision letter of Minister of Education and Culture No. 060/U/1993, which states that English could be taught at primary education starting from grade 4, may schools initiated it from grade 1 . As a result, even kindergartens followed it.

There are three reasons why does English at elementary school need in learning English. First, a young learner learn language easily; second, all of life systems uses English in this digital period, so that it can be easier to accept technology; third, the young learner accept English easily when they will continue to study at the junior high school [17]. It is therefore, English can be learned and mastered by students which include four skills namely, listening, speaking, writing and reading.

Reading is one of the four skills which is viewed as the most important language skill that should be developed in the classroom. Reading is defined as a human skill in which it is possible to interact with the written text, becoming one of the ways to acquire knowledge in a receptive way. Some previous studies have proven that reading is essential. In Indonesia, learning to read English starts at the fourth grade of elementary schools, and it continues at junior and senior high schools up to the higher education [10]. It can enhance people's social skills, improve hand-eye coordination, and provide people with endless hours of fun and entertainment.

Since English in Indonesia is a foreign language, most students at any levels of education get difficulty in reading English text. Many research results (Sariati, 2018; Fu, 2018; Sibarani, 2017; Muvidah, 2017; Karman, 2017; Damaianti, Damaianti and Mulyati, 2017; Kusuma, 2016; Hakim and Anggraini, 2015) indicated that the ability of Indonesian students to read English text was very low.

There are two statements why does reading is important to be learned. According to Pang in Arias [2], learning to read is an important educational goal for children and adults because the ability to read opens up new worlds and opportunities. In 
line with this statement, Clarke, Truelove, Hulme, and Snowling [4] reading becomes more important as children progress through educational system. Consequently, reading is central to teaching and learning and it is vital to consider the circumstances in which the developing child is required to extract and apply meaning derived from text material.

Materials take an important part in teaching learning process. It is in line with Dirgeyasa [5] as stated that there are some factors that play important role in the process of teaching and learning, namely learning materials, teaching methods, assessments, the students, and the lecturers. So that, materials are the most influencing, it is vitally important to evaluate the existing teaching materials. Considering with reading, it is very important to pay attention to give materials that appropriate with student's condition and students need. Good and appropriate materials will give positive influence to the students' learning process. In line with this, good material contains interesting text and enjoyable activities [11].

Januari 2019, an interview was conducted to the students of sixth grade at SDN 100107 Lobulayan to get preliminary data. Four questions were given to the students, for instances is the existing holiday text interesting?, is the existing holiday text easy?, is the existing holiday text useful?, and if you have not known the holiday text, do you find difficulties in comprehending it?. From the result of interview, some of the students think that the holiday text in the textbook used are quite interesting and difficult. They do not have background knowledge about the text. It can be concluded that, the existing holiday text are good to be used in the teaching and learning process but they are not close to students' live for the sixth grade students of SDN 100107 Lobulayan, South Tapanuli. Here is the interview excerpt with one of the student (Nd) "kadang-kadang, kadang menarik, kadang tidak. Tidak meanarik karena saya tidak mengerti dengan isi teks tersebut" (Januari 2019). (Sometimes, it is not interesting if I do not understand the content of the text).

To get the preliminary data, the researcher also observed the student's English book. Grow with English Book 6, English textbook is one of series of English books for elementary school sixth grade. In their books, it has found that reading materials are totally irrelevant with their needs. They often get confused because they didn't understand. Further, the researcher has found most of students were not good in comprehending the text. The students did not understand the content of the reading material given by the teacher. They just keep silent when the teacher read the texts in front of the class. Without being supported by teacher's explanation in Indonesian language, they couldn't understand at all about the content of the text given. Then, the students also have low motivation in studying and not active in the class. Last, teaching and learning process becomes a monotous activity. As a consequence, the students are difficult to comprehend the text. It is therefore the good materials that can fulfill the students need are required.

From the two reading texts about holiday in Malang, we went to Florida, are not North Sumatera or South Tapanuli students' real world. The students are not really familiar with them although they can also be input texts in receptive skills. However, it will be more meaningful if reading texts as inputs are about local based need at tourism destination topics and local culinary in South Tapanuli. Thus, the development of reading material English should be based on the characteristic of South Tapanuli regency.

Moreover, students' difficulties in comprehending the English reading materials affected their achievement in English subject. Grade VI students of SDN 100107 Lobulayan, for instances the average score in their formative 1 administrated by the teacher was still low, that is 6.6 with the Minimum Mastery Criteria (Kriteria Ketuntasan Minimal: $\mathrm{KKM})$ that should be achieved is 7.5.

Based on the fact stated previously, the researcher assumes that the facts will become a problem if not overcome soon. By doing this research, the researcher expected that this research can solve the problems stated previously by developing reading materials for elementary school through local based need. There are some reasons why does local based need. First, it is also urgent because by developing the reading material which involves local based need, the students are hoped to be able to improve their understanding about the material given since the material will be contextual and close with their culture and to be able to preserve the Angkola culture in the modernity of the globalization era. This is accordance with Firoz, Maghrabi, dan Kim statement [7] in relation to globalization is "Think globally manage culturally"Another reason for producing these kinds of materials is to help students become aware of their own cultural identity. Because the local based need of each place is different. Designing teaching materials for elementary students based on local need, where student learn their own local based need in order to talk about their tourism with the destinations.

In developing these reading materials, the researcher will insert local based need at tourism destination topics and culinary themes though English materials to solve those problems. Local based need means the needs of the students in Lobulayan area. There are two researchers previous why does local based needs is essential and really need in learning English. According to Dirgeyasa and Ansari [6], the local based need promotes and empowers the tourism resources locally to meet the needs of tourism industry. The local basedanalysis in tourism industry has an important and significant contribution to make to the quantities of natural and human resources. In line with Aspiandi, Sutapa, and Sudarsono studied recommend that local needs based materials. They also stated that teaching materials developed from the local needs have a good impact to learning activities.

Moreover, study related to the development materials for elementary school is applied out by Kusuma [15] conducted a study to develop reading material for fifth grade student at Elementary school in tourism area by inserting local culture. The result showed that reading material was developed by involving some of local contents and reading material had high validity and practicality and was proven to be effective. 
Based on the background of the study, the problems of the study are stated in the form of questions as below:

1. What are the existing English reading materials used by the sixth grade students at SDN 100107 Lobulayan in South Tapanuli regency?

2. What English reading materials are needed by the sixth grade students at SDN 100107 Lobulayan in South Tapanuli regency?

To answer the research problems, the objectives of the study are to:

1. To find out the existing English reading materials used for the students of sixth grade at SDN 100107 Lobulayan in South Tapanuli regency

2. To find out English reading materials are needed by the students of sixth grade at SDN 100107 Lobulayan in South Tapanuli regency

\section{LITERATURE REVIEW}

\section{A. Teaching English at Elementary School}

Elementary school is a unit of formal education in supervision of the minister of Education. Elementary school is what we call primary school. That is the first stage of education for younger children. According to Cambridge Dictionary Online, elementary school is a school that provides the first part of a child's education, usually for children between five and eleven years old.

Since the early 90s, English education has been introduced to some Elementary schools in Indonesia. The Indonesian Government through its Ministry of Culture and Education issued a decree number 060/U/1993 dated February 25th, 1993 stating that English can be taught at elementary school but only as part of local-content curriculum [23][24]. Also, Triana stated that concerning the principles of teaching English to young learners it is highly expected that the Indonesian government pay more attention to the teaching English at elementary school for the sake of sustainable development of human resource of Indonesian toward a better life. English language teaching (ELT), that is, the teaching of English as a second or foreign language, is usually portrayed in the professional literature as being primarily concerned with the mental acquisition of a language [12].

Indonesia has new curriculum that is curriculum 2013. Different from KTSP, in this curriculum English lesson just made extracurricular (Arif, 2015; Zein, 2016; Lestari, 2003). Based on the 2013 curriculum, English teaching covers cultures in efforts to strengthen local culture and identity which should be acquired by the students. This subject since it is helpful for student when they learn English in Junior High School. English at Elementary schools is now only a localcontent subject taught once a week.

In 2006 the Ministry of National Education (MoNE) released Decree No. 22/2006 on The Structure of National Curriculum. The decree stipulates English as a local content subject with an instruction period of up to $2 \times 35$ minutes per session [24][25]. Schools were given the freedom to start teaching English earlier than Grade 4 and were asked to implement a competency-based curriculum developed at the Local Education Unit (Kurikulum Tingkat Satuan Terpadu henceforth KTSP).

Elementary school students can be categorized as young learner, because they are in the early ages that start from six until twelve years old [19]. Starting enter elementary school, most of Indonesian students when they are six years old.

There some advantages of learning English as foreign language for the young learner. As brilliant publication 2014 in Arief [3] stated 10 reasons for teaching foreign languages in primary school, namely as follows:

1. Learning a new language is fun

2. It's best to start early

Brilliant publication in Arief [3] explains that primary pupils are very receptive to learning a new language. They are willing and able to mimic pronunciation without the inhibitions and self-consciuosness of older students.

3. Develops self confidence

4. Enriches and enhances children's mental development

Brilliant publication in Arif [3] mentioned international studies have shown repeatedly that foreign language learning increases critical thinking skills, creativity, and flexibility of mind in young children.

5. Improves children understanding of English

6. Encourage positive attitudes to foreign language

7. Broaden children's horizons

8. The ideal place to start

9. Help children in later career

10. It's great when you go holiday

\section{B. Reading}

Basically, reading is one of the kinds of skill in mastering English language. Reading is an activity that is done deliberately in order we can know what is wanted to know. Linse and Nunan [16] stated that Reading is a set of skills that involves making sense and deriving meaning from the printed word. It can be said that we must comprehend what we read. Further, Peregoy and Boyle in Linse and Nunan [16], there are three different elements which impact reading for second language learners, namely the child's background knowledge, the child's linguistic knowledge of the target language, and the strategies or techniques the child uses to tackle the text.

Suyanto [21] divides six stages the process of learning to read in general can go through as the following stages:

1. Read (pronounce) alphabet with English pronunciation ap-p-l-e

2. Read words that can also be accompanied by reciting or spelling like: apple

3. Read phrases forwarded to short sentences

4. Read sentences that are meaningful or contain messages, either in the form of a question (question) or statement sentence (statement)

5. Reading discourses, short writings, or other materials, such as dialogue, poetry, and letters.

6. Reading discourses, longer dialogues, stories, or events.

From the explanation above, reading skills are taught from words, phrases, then discourses with easy vocabulary to more 
difficult vocabulary, from short to longer discourses with more varied grammar. The level of difficulty and the length of the reading material are adjusted to the level of children's language development and level of the class.

Moreover, Suyanto [21] stated that teaching materials are what the teacher uses to give to students in order to achieve certain competencies or abilities, as previously planned. Teaching materials can be obtained from various sources, among others in the form of, as follows:

1. textbook (student book),

2. teacher's book,

3. Tapes or CDs,

4. Picture cards,

5. Poster,

6. Results of research or study,

7. Various recordings of experiences that are relevant to subjects or courses that are fostered,

8. Scientific articles and conceptual writing

9. Note the experience of teachers and lecturers

10. Brochures, manuals and other relevant material

EYL teaching materials have their own characteristics because of the limitations associated with children's language development, language functions, and the state of society. Suyanto [21] include eight characteristics the following:

1. Grammar is very simple

2. The type and completeness of the vocabulary need to be given because there is almost no English exposure outside the classroom.

3. Vocabulary is limited to about 500 words

4. Materials need to be accompanied by pictures

5. Students hardly hear English around it, so it needs repeated pronunciation exercises

6. Students do not have time to practice so teaching materials must be easy to understand and vary.

7. Vocabulary used is everyday language and is simple for communication

8. Easily available maybe there are students who do not have textbooks.

\section{Concept Local based Needs}

Local is a place or local conditions. According to Salazar [18] defined the local not only refers to a spatially limited locality; it is above all a space inhabited by people who have a particular sense of place, a specific way of life, and a certain ethos and worldview. Need is something that a person must have and that is needed in order to live or succeed or be happy. A need can felt by an individual, a group, or an entire community. Needs, it can be defined as the gap between what is and what should be.

In this study, "needs" refer to the needs of the learners and "local" refers to the Lobulayan area school. Thus, the local needs mean here the needs of the students in Lobulayan areas. In line with Aspiandi, Sutapa, and Sudarsono defined local needs is the needs of the students in an area.

In addition, Dirgeyasa and Ansari [6] stated that theoretically and empirically, the local needs promotes and empower the tourism industry. It is also relevant to the statement "think globally and act locally". Further, they also defined local based needs as all resources showing the typical characteristic of a certain region in terms of economy, culture, natural features and its people, which are different from the other regions.

Furthermore, Nangsari and Dwitagama in Dirgeyasa and Ansari [], defined the local-based need is a matter of local competitiveness with regard to natural resources, human resources, culture and tradition and services which are typically unique and different.

Like the term 'local based needs', the term 'keunggulan lokal' also defined as a process and realization of increasing the value of a regional potential so that it becomes a product and service or other high-value work that can add to the income of each region without exception is unique and has a comparative advantage [1]. However, this paper tended to use the term 'local based needs'. Simply, the researcher concluded that local based needs here the needs of the students in Lobulayan areas.

South Tapanuli is a district in North Sumatra, Indonesia, where the capital is Sipirok. This district was originally a very large district with capital in Padang Sidempuan. The areas that have been separated from South Tapanuli is Mandailing Natal and Padang Sidempuan, North Padang Lawas and South Padang Lawas. After the expansion, the district capital moved to Sipirok. The language that being used is the language of Batak Angkola with majority religion is Islam.

South Tapanuli regency has such as unique and potential local destination/tourism and local culinary. The topic that go with this uniqueness such as Aek Sijornih Baths, Silima-lima waterfall, Lake Siais, Napa waterfall, Aek Milas Sosopan, Parsariran Baths, Simago-mago Hills, Sisundung waterfall, Sisoma waterfall, and etc while for local culinary/food, includes sambal taruma, ikan sinyar-nyar, gule bulung gadung, pangggelong and etc. All topics are chosen shown in the table presented below:

TABLE 1. ENGLISH TOURISM TOPICS OF NATURAL RESOURCES

\begin{tabular}{|l|l|}
\hline No & Topics \\
\hline 1 & Aek sijornih baths \\
\hline 2 & Parsariran Baths, \\
\hline 3 & Silima-lima waterfall \\
\hline 4 & Napa waterfall \\
\hline 5 & Sisundung waterfall, \\
\hline 6 & Sisoma waterfall, \\
\hline 7 & Simago-mago Hills, \\
\hline 8 & Lake articifial cekdam \\
\hline 9 & Lake marsabut \\
\hline 10 & Lake Siais \\
\hline 11 & Aek Milas Sosopan \\
\hline 12 & Benteng huraba \\
\hline 13 & Torsibohi hotel \\
\hline
\end{tabular}

As indicated in Table 1 Aek Sijornih baths, Parsariran baths, Silima-lima waterfall, lake Siais are very familiar for students. Actually, it is not surprisingly why they are familiar. Aek sijornih, for example, is the most beautiful baths and also has waterfall in the South Tapanuli. 


\section{Material Development}

In line with the guidelines of developing material, Tomlinson [22] provides some principles materials for the teaching of language which are presented below:

1. material should achieve impact

2. Materials should help learners to feel at ease

3. Material should help the learners to develop confidence

4. What is being taught should be perceived by learners as relevant and useful

5. Materials should require and facilitate learner selfinvestment

6. Learner must be ready to acquire the points being taught

7. Materials should expose the learners to language in authentic use

8. The learners ${ }^{\text {ee }}$ attention should be drawn to linguistic features of the input

9. Materials should provide the learners with opportunities to use the target language to achieve communicative purposes

10. Materials should take into account that the positive effects of instruction are usually delayed

11. Material should take into account that learners differ in learning styles

12. Materials should take into account that learners differ in affective attitudes

13. Material should permit a silent period at the beginning of instruction

14. Material should maximize learning potential by encouraging intellectual,

15. Material should not rely too much on controlled practice

16. Material should provide opportunities for outcome feedback

Designing tasks is not the final step in material design. The materials, then, need to be evaluated through the process of material evaluation. Hutchinson and Waters [11] state that evaluation is a matter of judging the fitness of something for a particular purpose. They add that in the process of evaluation, there is no absolute good or bad- only degree of fitness for the required purpose. In other words, material evaluation can be defined as an activity to measure whether the material meets learners' need or not.

Hutchinson and waters [11] define needs as the ability to comprehend and to produce the linguistic features into two categories; target needs and learning needs. The target needs are what knowledge and abilities the learner will require in order to be able to perform appropriately in the target situation. The analysis of the target needs is divided into three points which are necessities, lacks, and wants.

a. Necessity is defined as the type of needs determined by the demands of the target situation.

b. Lacks is the gap between what the learners know already and what the learners do not know.

c. Wants is what the learners expect about language area that they want to master.

\section{METHODOLOGY}

This was research and development ( $R$ and $D)$ study which aimed to develop effective product based on the result of need analysis. It was conducted to design reading materials based on local based needs for the students of sixth grade of elementary schools in Lobulayan. Borg and Gall [9] state that $\mathrm{R}$ and $\mathrm{D}$ is a process to develop and validate the educational product by testing it. They suggest that the product should be systematically field-tested, evaluated, and refined until they meet specified criteria of effectiveness, quality, or similar standards. But in implementing the model is simplified and adapted to Dirgeyasa [] become four steps: 1) evaluation and need analysis, 2) developing new material, 3) validating material, 4) final revision.

The respondents of the research were the sixth grade students of SDN 100107 Lobulayan. The total numbers of the sixth grade students were 29 persons. 1 English teacher they are taken by using total sampling technique, 2 lecturers and 1 stakeholder is taken by using random sampling technique.

The instruments of the research were questionnaire, interview, and documentary sheet. There were two kinds of questionnaire used. The first questionnaire is for the students and the teachers to identify the needs of local based needs reading materials for sixth grade of elementary school in Lobulayan. The second questionnaire is for expert judgment to evaluate the material developed.

The data would be analyzed quantitatively and qualitatively. The questionnaire consisted of several questions which asked the students and teachers to choose the answer based on their experience in teaching and learning reading.

The questionnaire would be analyzed by using descriptive technique. To determine the reading materials are feasible or not, a parameter is needed. Detail description of the categorization is shown in Table 2

TABLE 2. PARAMETER OF VALIDATING THE READING MATERIAL

\begin{tabular}{|c|c|c|}
\hline No & Range of Score & Level of Feasible \\
\hline 1 & $101-125$ & Excellent \\
\hline 2 & $75-100$ & Good \\
\hline 3 & $50-74$ & Fair \\
\hline 4 & $25-49$ & Poor \\
\hline 5 & $0-24$ & Very Poor \\
\hline
\end{tabular}

(adapted from Dirgeyasa, 2011)

For interviewing section is conducted to dig deeper and comprehensive about need analysis in stake-holder, alumni and English teacher. The results of interview are analyzed by descriptive technique. Detail description of the categorization is shown in Table 3

TABLE 3. THE CATEGORIZATION OF NEED CRITERIA

\begin{tabular}{|c|c|c|}
\hline No & Range of Score & Level of Need \\
\hline 1 & $0-0.5$ & Not Needed \\
\hline 2 & $0.6-1.5$ & Less Needed \\
\hline 3 & $1.6-2.5$ & Fairly Needed \\
\hline 4 & $2.6-3.5$ & Needed \\
\hline 5 & $3.6-4.0$ & Very Needed \\
\hline
\end{tabular}

(adapted from Dirgeyasa and Ansari, 2015) 
This parameter determine whether the existing syllabus and reading materials relevant or not. It is shown in Table 4 as follow:

TABLE 4. THE RELEVANCE CATEGORIZATION CRITERIA FOR EVALUATION OF SYLLABUS, EXISTING MATERIAL AND LEARNING OF READING SITUATION.

\begin{tabular}{|c|c|c|}
\hline No & Range of Score & Level of Relevant \\
\hline 1 & $0-0.5$ & Not Relevant \\
\hline 2 & $0.6-1.5$ & Less Relevant \\
\hline 3 & $1.6-2.5$ & Fairly Relevant \\
\hline 4 & $2.6-3.5$ & Relevant \\
\hline 5 & $3.6-4.0$ & Very Relevant \\
\hline
\end{tabular}

(adapted from Dirgeyasa and Ansari, 2015)

\section{RESEARCH FINDINGS AND DISCUSSION}

The study was conducted by developing the need analysis to know the local based needs by the students toward their reading materials. In achieve that intention so this research has been done by educational Research and Development model. This research has been done by four steps; evaluation and need analysis, course design, validation, revision and final product. The result can be seen as shown in the below:

\section{A. The existing reading material}

Evaluation process on existing materials especially about reading text in Grow with English by Erlangga press was done in order to find out whether the existing reading text provided by the teacher. The checklist was done for determining of the relevance of properness of the existing material with the students' need in learning English especially in reading.

From the analysis of the existing materials from five main aspects; the purpose, design and arrangement, linguistic features, topics, and methods got 0.95 point. Based on likert scale can see in Table 3.3 can conclude that the existing reading material were less relevant for elementary school.

It can be concluded that the existing material are good to be used in teaching and learning process but they are not close for the sixth grade students of elementary school in Lobulayan.

\section{B. Need analysis}

Need analysis as the important source data after evaluation process. To collect the data was collected from stakeholder, alumni, English teacher, and students of elementary school.

The result of analysis of need analysis was done by the students, stakeholder, alumnus, English teacher conclude that the important need for students that can be implemented their knowledge in the factory must be correlated with the topics of natural resources (local tourism destination such as holiday in Aek Sijornih baths, Silima-lima waterfall, Parsariran baths ), and social culture (traditional food and drink, traditional clothes).

The aspects of this evaluation need analysis consist of four main aspects. The aspects covered a) the reading materials, b) linguistic features, c), design and layout d) topic needed.

The interview section has done by an English teacher and alumnus. This interview was conducted to know about the need after they graduate from the school. The results of the interview were analyzed by descriptive technique.

1. Alumnus

When the studied at school, the English skill cannot support with the needs of local knowledge because it never studied before. So the alumnus need about reading text which has correlation with their local based needs at school especially about local vegetables, tourist places name, traditional clothes, names of governor or country in English, local food or culinary.

2. English teacher

The topics given for sixth grade are traditional clothes, names of tourist place, local food, local fruits, about family, school objects. There are some terms in elementary students books used English, so they need to study English about local based needs in South Tapanuli.

Need analysis was done in order to find out the basic competences which need to be reached by elementary students to increase the students' motivation in learning English. From the result of questionnaire has given to the students, the result of interview was given to the stakeholder, alumnus, and English teacher, that data were taken become a reference for developing a new reading material through local based need in South Tapanuli.

The result of this research is similar with Kusuma [15]. Kusuma [15] found that the existing materials were not contextual for the students of fifth grade of elementary schools in Buleleng regency, Bali. Next, Hakim and Anggraini [] focuses on developing English textbook for fourth grade students in Elementary school. The researcher developed English textbook based on CTL. For the result, the form of student's book was developed based on the 2006 English curriculum. The student's book was developed into six units which stated the basic competences, the topic, and the learning outcomes. The topics were developed into task and were related to the student's context and workplace. In this 
research, most students think the existing text do not always suit with the students' background. It is difficult for the students to acquire the language and the text at the same time. They believe that if the students have background knowledge about the text, they will be easy in comprehending it. Then it is suggested to the teachers to suit the reading material with students' background knowledge [22].

It has been proved by many researchers that using localbased needs material in language teaching classroom is a great advantage to both students and teachers. First, it is a effective way to use of local texts in teaching foreign language class and it will make the students motivated because local needs contents involve the topics which the students are familiar with. As stated by Al Mahrooqi and Al Busaidi (2010), "local needs can be met more effectively". In addition, Aspiandi, Sutapa, and Sudarsono also stated local needs have a good impact to learning activities. Futhremore, Dirgeyasa and Ansari [6] local based needs promotes and empowers the tourism resources locally to meet the needs of tourism industry.

It can be concluded that, they can encourage learners to gain a deeper understanding of their own local needs and to share these insights in it. Next, using the local-based needs materials can make learner easier in learning the contents because they are familiar with those topics and have previous background knowledge about them. Moreover, providing local needs contents in foreign language class can also easier motivate the learner to explore their knowledge more and be more enthusiastic in class. Related to the term of local culture, $\mathrm{Fu}[8]$ stated that the use of local culture contents is one of the effective ways to stimulate students' motivation in language class.

\section{REFERENCES}

[1] Ahmadi, I. K. A, S. and T. Elisah, 2012. Mengembangkan Pendidikan Berbasis Keunggulan Lokal dalam KTSP. Jakarta: PT. Prestasi Pustakaraya.

[2] Arias, I. J,. 2007. Selecting Reading Materials Wisely, Universidad Nacional. Costa Rica. LETRAS 41.

[3] Arief, N. 2015. Removing English as Compulsory Subject from Primary Schools on the 2013 Curriculum based on Teacher's Opinion. International Journal of Scientific and Research Publications (IJSRP). Vol. 5. Issue 8.. p.1-5

[4] Clarke, Paula J., Emma Truelove, Charles Hulme and Margaret J. Snowling. 2014. Developing Reading Comprehension. USA: John Wiley \& Sons, Ltd.

[5] Dirgeyasa, I. Wayan. 2014. The development of English Writing Learning Material through a Genre Based Approach for English Department at University. SELT, Padang, June 11-12. p. 200-209.
[6] Dirgeyasa, I. Wayan and Ansari, K. 2015. The Study of Need Analysis of Tourism Topics and English Linguistics Features through Localbased Needs at the Golden Riangle Tourism Destination in North Sumatra Province Indonesia. Asian EFL Journal Professional Teaching articles/ issue 86. p. 4-24.

[7] Firoz, N.M, Maghrabi, A.S dan Kim, K.H. 2002. Think globally manage culturally. International Journal of Commerce Management. Indiana: Vol. 12, Iss.3/4: pg 32, 19 pgs

[8] Fu, W. 2018. Read from Local to Global: A Culture-based Reading Material. Advances in Social Sciences Research Journal, 5(3) 57-65.

[9] Gall, M, D., Gall, J. P., \& Borg, W. R. 2003. Educational Research an Introduction; Seventh Edition. USA: Pearson Education.

[10] Hamra, A. and Syatriana, E. 2010. Developing a Model of Teaching Reading Comprehension For EFL Students. TEFLIN Journal, Volume 28 21, No. 1. p. $27-40$

[11] Hutchinson, T., and Waters, A. 1987. English for Specific Purposes: A learning Centered Approach. Cambridge: Cambridge University Press.

[12] Johnston, B. 2003. Values in English Language Teaching. London: Lawrence Erlbaum Associates, Publishers.

[13] Karman. 2017. Developing English Reading Materials for Madrasah Aliyah Students. Langkawi Journal, Vol.3 No.1. p.45-62.

[14] Khan, Intakhab A. 2016. Local Culture in the Foreign Language Classrooms: An Exploratory Study of Teacher's Preparedness in Saudi Arabia. International Journal of Sciences: Basic and Applied Research (IJSBAR). Volume 25, No 1, pp 97-122.

[15] Kusuma, I P. Indra. 2016. Developing Reading Material for Elementary Students in Tourism Area by Inserting Local Culture. JEELS, Vol. 3, No.1.p.109-127.

[16] Linse, C. and D. Nunan. 2005. Practical English language teaching PELT Young Learners Englishaas a second language. New York: McGraw-Hill, Inc

[17] Maili, S. Nursiti. 2018. Bahasa Inggris pada Sekolah Dasar: Mengapa Perlu dan Mengapa Dipersoalkan. Jurnal Pendidikan UNSIKA (JUDIKA). Vol. 6.No.1 p.23-28.

[18] Salazar, N. B. 2004. Tourism and Glocalization "Local" Tour Guiding. Annals of Tourism Research. Vol.20. No.20. p.1-19.

[19] Sepyanda, M. 2017. The Importance of English Subject in Elementary School Curriculum. English Language Teaching and Research. Vol. 1. No.1 September. p. 206-216.

[20] Sibarani, I. Sabrina. 2017. Developing the Students' Reading Materials through Authentic Material for Grade XI Students of the Marketing Department at State Vocational High School SMKN 1 Pemtangsiantar. Unpublished thesis, Universitas Negeri Medan, Medan, Indonesia.

[21] Suyanto, Kasihani K.E. 2014. English for Young Learners: Melejitkan Potensi Anak melalui English Class yang Fun, Asyik, dan Menarik. Cet. ke-4. Jakarta: Bumi Aksara.

[22] Tomlinson, B. 2011. Materials Development in Language Teaching. United Kingdom: Cambridge University Press.

[23] Triana, N. 2017. English Education at Elementary School in Japan Universitas Negeri Malang. Premise Journal. Vo. 6 No.1 April. p.20-28.

[24] Zein, M. Subhan,. 2017. Elementary English Education in Indonesia: Policy Developments, Current Practices, and Future Prospects. English Today 129, Vol. 33, No. 1 March. p.53-59.

[25] Zein, Subhan. 2016. Pre-service Education for Primary School English Teachers in Indonesia; Policy Implications. Asia Pacific Journal of Education. Vol. 36. No. S1. p.119-134. 